\title{
Evaluasi Pelaksanaan Program Full Day School di Sekolah Menengah Kejuruan
}

\author{
Nila Oktaviana Kumang; Bambang Suteng Sulasmono
}

Prodi Magister Administrasi Pendidikan

Fakultas Keguruan Dan Ilmu Pendidikan Universitas Kristen Satya Wacana

Jalan Diponegoro 52-60 Salatiga Jawa Tengah Indonesia

nilaoktavianak@gmail.com

Article received : April 2020; revised : June 2020 ; accepted : July 2020

DOI : 10.17977/um025v4i32020p182

\begin{abstract}
This study aims to evaluate the implementation of the full day school (FDS) program at Public Vocational High School 1 Pabelan. This type of research is evaluative research with descriptive qualitative methods using CIPP as an evaluation model. Data collection techniques using interviews, observation, and documentation. The results showed: (1) the context component was categorized as good because the FDS program was indeed needed by all stakeholders and parents, not just implementing policies from the government; (2) the input component is categorized as sufficient because it responds to the needs of all stakeholders and parents, adequate infrastructure and funds, the mechanism of implementing activities is clear, but the human resources of the number and competence of teachers are still lacking; and (3) the process component gets enough categories, because $80 \%$ of the programs are implemented according to plan, the resources are quite functional because the teacher facilitates the needs of students; although the funds provided are sufficient, but from the infrastructure, the number and competence of teachers is still lacking; and (4) the product component gets an adequate category because academic results do not show an increase, nonacademic achievements have an increase but are not significant. Nevertheless, the objectives of implementing the FDS program were achieved because the students' character improved.
\end{abstract}

Keywords: full day school; character education; CIPP

Abstrak: Penelitian ini bertujuan untuk mengevaluasi pelaksanaan program full day school (FDS) di SMK Negeri 1 Pabelan. Jenis penelitian ini ialah penelitian evaluatif dengan metode kualitatif deskriptif menggunakan CIPP sebagai model evaluasi. Teknik pengumpulan data menggunakan wawancara, observasi, dan dokumentasi. Hasil penelitian menunjukkan: (1) komponen konteks mendapat kategori baik karena program FDS memang dibutuhkan oleh seluruh stakeholder dan orangtua, bukan hanya menerapkan kebijakan dari pemerintah; (2) komponen input mendapat kategori cukup karena menjawab kebutuhan seluruh stakeholder dan orangtua,sarana prasarana dan dana memadai, mekanisme pelaksanaan kegiatan jelas, tapi sumber daya manusia dari jumlah dan kompetensi guru masih kurang; dan (3) komponen proses mendapat kategori cukup, karena $80 \%$ program dilaksanakan sesuai rencana, sumber daya cukup fungsional karena guru memfasilitasi kebutuhan siswa; meskipun dana yang disediakan cukup, tetapi dari sarana prasarana, jumlah dan kompetensi guru masih kurang; dan (4) komponen produk mendapat kategori cukup karena hasil akademik tidak menunjukkan adanya peningkatan, prestasi non akademik ada peningkatan tetapi tidak signifikan. Meskipun demikian, tujuan dari pelaksanaan program FDS tercapai karena karakter siswa membaik.

Kata Kunci: full day school; pendidikan karakter; CIPP 
Urgensi masalah pendidikan yang dialami Indonesia pada masa ini seiring dengan arus globalisasi yakni dihadapkan pada kecendrungan semakin merosotnya karakter bangsa dan khususnya generasi muda ditandai dengan perilaku-perilaku yang menunjukan gejala-gejala tindakan amoral yaitu berperilaku tidak sopan, terjadinya kriminalitas, sexs bebas, tawuran, kasus bullying di sekolah dan tindakan amoral lainnya (Ningrum, 2015; Kurniawan, dkk., 2019). Bentuk upaya pereventif pencegahan degradasi moral anak yaitu dengan menciptakan pendidikan moral di sekolah sebagai upaya meningkatkan karakter siswa disekolah yaitu dengan adanya program penguatan pendidikan karakter (PPK).

Penerapan PKK pada 5 hari sekolah dapat disebut dengan program full day school (FDS), yang tertuang pada Permendikbud Nomor 23 Tahun 2017 tentang Lima Hari Sekolah disebutkan bahwa FDS ialah program untuk menyiapkan siswa untuk menghadapi pelbagai tantangan yang ada seiring dengan berkembangnya globalisasi. Untuk itu, dibutuhkan peneguhan karakter bagi siswa dengan pembenahan pendidikan karakter disekolah serta mengoptimalisasi peran sekolah. Pelaksanaan FDS yakni 8 jam pada 1 hari dan 5 hari pada 1 minggu. Model yang dikembangkan pada program FDS yakni penggabungan antara pendidikan agama dan umum untuk memaksimalkan potensi siswa dari segi pengetahuan, pendidikan karakter serta non akademik (Soapatty, 2014). Urgensi FDS yakni sebagai upaya agar sikap sosial maupun spiritual siswa membaik dan meningkat sehingga krisis moral pada siswa dapat teratasi, membantu orangtua yang sibuk bekerja sehingga terwujudnya pengawasan terhadap anak (Baharuddin, 2010).

Penelitian yang dilakukan oleh Danil (2018) menunjukan bahwa FDS memberikan dampak yang positif bagi perkembangan anak yakni pada penanaman nilai-nilai karakter dengan didukung oleh situasi atau suasana lingkungan sekolah yang tidak membuat jenuh atau menyenangkan serta adanya pengawasan oleh guru. Sedangkan penelitian yang dilakukan oleh Apriyani, dkk., (2018) menunjukkan bahwa program FDS memberikan dampak dan kendala, sehingga SMA Negeri 1 Kedungreja Kabupaten Cilacap yang menerapkan program FDS kembali menerapkan 6 hari sekolah dikarenakan mengalami pelbagai kendala sehingga mempengaruhi kualitas dari pembelajaran, pelaksanaan pembelajaran tidak menunjukan perubahan setelah menerapkan FDS. Berdasarkan penelitian-penelitian tersebut, ada penelitian yang menunjukkan bahwa program FDS dapat meningkatkan karakter peserta didik, namun ada juga penelitian yang hasilnya tidak demikian.

Salah satu sekolah yang menerapkan program FDS yakni SMK Negeri 1 Pabelan telah diterapkan sejak tahun ajaran 2017/2018. Berdasarkan wawancara awal kendala yang dampak sehubungan dengan program FDS yakni kurang lengkapnya sarana dan prasarana. Padahal FDS dapat mempengaruhi dan berdampak prestasi akademik perserta didik apabila ada kesesuaian antara fasilitas penunjang terhadap keadaan atau kebutuhan perserta didik, kurikulum serta kreatifitas yang dimiliki oleh guru (Soapatty, 2014). Persoalan lain yang muncul dengan diterapkannya program FDS di SMK Negeri 1 Pabelan yakni dengan bertambahnya durasi belajar disekolah mengakibatkan siswa merasa jenuh dan sering mengalami kelelahan secara fisik seperti mengantuk pada saat jam pelajaran berlangsung dan pada waktu siang hari. Untuk itu, program FDS ini penting untuk dievaluasi karena diduga mempengaruhi efektivitas pembelajaran siswa.

Evaluasi yakni suatu proses dalam menentukan hasil dari beberapa kegiatan yang telah direncanakan dalam rangka mendukung tercapainya tujuan (Arikunto \& Jabar, 2010). Evaluasi program yakni proses dalam menemukan sampai dimana sasaran atau pun tujuan tercapai, penyediaan informasi bagi pengambil keputusan, membandingkan kinerja terhadap patokan untuk mengetahui bila adanya kesenjangan, serta penyelidikan sistematis menyangkut nilai/kualitas suatu objek (Ananda \& Rafida, 2017). Suatu program penting dan perlu untuk dievaluasi agar menentukan intervensi atau pun layanannya telah terealisasikan sesuai dengan tujuan yang telah dibuat (Wirawan, 2012). Penelitian evaluasi bertujuan guna mengevaluasi pelaksanaan program FDS pada SMK Negeri 1 Pabelan, menggunakan model evaluasi CIPP (Context, Input, Process, Product). CIPP merupakan model evaluasi komprehensif dalam mengarahkan penyelenggaraan evaluasi formatif dan sumatif pada objek tertentu baik proyek, program, personalia, instusi, sistem maupun produk (Wirawan, 2012). 


\section{METODE}

Penelitian ini dilakukan guna mengevaluasi bagaimana penyelenggaraan program FDS pada SMK Negeri 1 Pabelan. Penelitian evaluatif ini menggunakan metode kualitatif deskriptif dengan CIPP sebagai model evaluasi. Teknik pengumpulan data yakni wawancara, observasi serta dokumentasi. Subjek penelitian yakni kepala sekolah, wakil kepala sekolah bidang kurikulum, satu guru bimbingan konseling, serta masing-masing satu perwakilan perserta didik kelas X, XI, XII.Validasi data yakni menggunakan triangulasi teknik dan sumber. Analisis data memakai interaktif model yang dikembangkan Miles dan Huberman yakni kegiatan pengumpulan data, reduksi data, penyajian data, dan penarikan kesimpulan/ verifikasi data.

\section{HASIL DAN PEMBAHASAN}

Program FDS di SMK Negeri 1 Pabelan dimulai sejak tahun ajaran 2017/2018. Program FDS diawali oleh adanya kebijakan dari pemerintah pusat yang mengatur 5 hari sekolah dan resmi diterapkan pada tahun ajaran 2017-2018.

\section{Evaluasi Konteks Program FDS di SMK Negeri 1 Pabelan}

Evaluasi Konteks pada program FDS ini menggambarkan tentang awal dari program FDS yakni latar belakang yang mendasari terwujudnya program FDS menyangkut analisis kebutuhan, tujuan dari program FDS serta manfaat. Berdasarkan wawancara terhadap stakeholder latar belakang program FDS di SMK Negeri 1 Pabelan yakni program ini dilaksanakan sesuai dengan aturan pemerintah yang ada pada Peraturan Kementerian Pendidikan Dan Kebudayaan Nomor 23 Tahun 2017 Tentang Hari Sekolah, dimana hari belajar siswa yang awalnya 6 hari dirubah menjadi 5 hari sekolah. Dengan pertimbangan sekolah yakni didasarkan pada peningkatan kualitas pendidikan dan menimbang kebutuhan orangtua akan pentingnya pengawasan anak terkait dengan mobilisasi kebanyakan orangtua sibuk bekerja. Tujuan dari diterapkannya program FDS di SMK Negeri 1 Pabelan yaitu peningkatan kualitas dengan memakismalkan waktu pembelajaran disekolah sehingga dapat berimplikasi pada perkembangan kompetensi yang dimiliki siswa baik pendidikan karakter, prestasi akademik dan non akademik sehingga kualitas pendidikan menjadi lebih baik. Manfaat dari program FDS di SMK Negeri 1 Pabelan yakni siswa dapat memperoleh pengetahuan lebih melalui pendalaman materi, terbentuknya pendidikan karakter dan mengembangkan potensi membantu pengawasan siswa. Hal ini sejalan dengan penelitian Leasa \& Batlolona (2017), hasil penelitiannya menunjukkan bahwa manfaat FDS yakni menumbuhkan nilai-nilai positif bagi siswa, sehingga dapat terbentuknya pribadi yang berkarakter ataupun integritas.

Berdasarkan hasil evaluasi dan pemenuhan keriteria evaluasi maka dapat disimpulkan bahwa dari komponen konteks program FDS di SMK Negeri 1 Pabelan termasuk kategori baik, karena program FDS dibutuhkan oleh seluruh stakeholder dan sekolah serta orangtua, tidak hanya sebagai perwujudan dari kebijakan pemerintah. Kebutuhan sekolah yakni untuk meningkatkan kualitas pendidikan sedangkan kebutuhan orangtua yakni membantu pengawasan anak.

\section{Evaluasi Input Program FDS di SMK Negeri 1 Pabelan}

Di SMK Negeri 1 Pabelan telah dilakukan perencanaan sebelum program FDS diterpakan. Perencanaan dilakukan pada awal tahun ajaran baru 2017 dan berakhir pada evaluasi akhir semester yakni 2018. Rencana ataupun jadwal program FDS di SMK Negeri 1 Pabelan secara garis besar dimulai dari analisa kebutuhan (sekolah menimbang pentingnya program FDS baik untuk siswa dan kepentingan semua warga sekolah), rancangan pembelajaran (perubahan jadwal pembelajaran dan perangkat pembelajaran), penyelenggaraan kegiatan dengan pemenuhan tiga aspek pendidikan yaitu akademik, psikomotorik, pendidikan karakter. SDM yang terlibat dipilih sesuai kriteria dan keahlian. Pendanaan program FDS di SMK Negeri 1 Pabelan bersumber dari pemerintah yaitu dari dana BOS, BOP serta PSM dan dilaporkan dalam bentuk dokumen pada rencana kegiatan dan penganggaran sekolah. Sarana dan prasarana direncanakan sesuai dengan kebutuhan. 
Berdasarkan hasil penelitian dan pemenuhan keriteria evaluasi dapat disimpulkan bahwa program FDS di SMK Negeri 1 Pabelan pada komponen input mendapatkan kategori cukup, dikarenakan program menjawab kebutuhan sekolah dan orang tua dalam upaya peningkatan kualitas serta pengontrolan perilaku siswa, dari segi sumber daya manusia yakni guru yang menjadi penanggung jawab kegiatan dipilih sesuai dengan keahlian dalam bidangnya, dari segi pendidikan akademik kualifikasinya sudah memenuhi kualifikasi akademik pendidikan minimum yakni sebagian besar guru S1 dan beberapa S2. Tetapi dari segi jumlah guru masih kurang yakni total jumlah guru 39 orang dan dari jumlah tersebut 28 orang guru belum menjabat sebagai Pegawai Negeri Sipil. Hal tersebut menunjukan bahwa dari segi jumlah guru masih kurang memadai dan dari segi kompetensi profesional masih banyak Guru Tidak Tetap. Namun perencanaan sarana dan prasarana sesuai dengan kebutuhan FDS dan dana memadai. Selain itu, SMK Negeri 1 Pabelan memiliki mekanisme pelaksanaan yang jelas. Hal ini sejalan dengan hasil penelitian Siregar (2017) yakni FDS dapat dilaksanakan dengan efektif ketika sekolah mampu memanfaatkan dan mengelola sumber daya yang dimiliki seperti halnya fasilitas, pendidik, maupun kurikulum.

\section{Evaluasi Proses Program FDS di SMK Negeri 1 Pabelan}

Implementasi program FDS di SMK Negeri 1 Pabelan sudah terselenggara dengan baik dan sistematis sesuai dengan perencanaan, dari awal hingga dilakukan evaluasi. Hal tersebut sesuai dengan dokumen program kerja sekolah (PKS) SMK Negeri 1 Pabelan tahun diklat/2018/2019 sub komponen kegiatan program pembelajaran 5 hari sekolah indikator keberhasilan, guru dan siswa antusias melaksanakan pembelajaran 5 hari sekolah dengan jadwal tersusun dengan baik dan pencapaian target sudah $80 \%$. Pendanaan mencukupi keseluruhan kegiatan dan sesuai perencanaan. Namun dari berbagai aspek pelaksanaan program FDS, sarana dan prasarana serta sumber daya manusia masih kurang.

Berdasarkan evaluasi proses perencanaan hingga pelaksanaan sudah tertata secara sistematis dengan baik tanpa ada yang terlewatkan sesuai dengan rencana. Berjalannya mekanisme ini sejalan dengan aturan FDS atau Full Time School di Negara mexico yang dimana penerapan FDS atau Full Time School harus memenuhi kriteria dimana program memiliki cakupan yaitu adanya pendanaan mencakup pengembangan SDM, sarana dan prasarana, adanya pemantauan dan dukungan konseling untuk sekolah (Zermeño, dkk., 2014).

Pendanaan program FDS di SMK Negeri 1 Pabelan memadai dan mencukupi. Dana terorganisir dengan baik sehingga dapat mengoptimalisasikan layanan pendidikan.Sekolah menata dan mengelola dan mengorganisir dana sesuai kebutuhan, sehingga tidak ada permasalahan terkait dengan pendanaan di SMK Negeri 1 Pabelan. Fasilitas atau sarana prasarana sudah cukup baik, namun kurang dari segi jumlah. Jumlah peralatan praktek belum mengakomodasi banyaknya siswa. Sehingga tidak jarang siswa memakai 1 alat secara bergiliran dan berkelompok. Sementara hasil penelitian Tia, dkk., (2019) menyatakan bahwa implementasi program FDS belum sepenuhnya berjalan dengan baik, bila dukungan dari fasilitas kurang memadai yang mencakup peralatan, fasilitas ekstra, dan fasilitas guru.

Dari segi SDM, guru sudah mengajar dan memfasilitasi siswa dan mengajar sesuai dengan keahliannya, sudah memenuhi kualifikasi akademik guru. Namun dari segi jumlah dan kompetensi masih kurang yakni masih banyak guru yang berstatus tidak tetap. FDS dapat dilaksanakan dengan efektif ketika sekolah mampu memanfaatkan dan mengelola sumber daya yang dimiliki seperti halnya pendidik (guru sekolah), sarana dan prasarana pendidikan serta kurikulum (Siregar, 2017).

Berdasarkan hasil penelitian dan pemenuhan kriteria evaluasi dapat disimpulkan bahwa program FDS di SMK Negeri 1 Pabelan pada komponen proses mendapatkan kategori cukup, hal ini ditunjukan oleh kegiatan-kegiatan terlaksana dengan baik, sumber daya cukup fungsional dikarenakan guruguru mengayomi dan memfasilitasi kebutuhan siswa dan memiliki keahlian dalam bidangnya, serta pembelajaran sudah menggunakan media meskipun dari segi jumlah guru masih kurang dan masih banyak guru yang tidak tetap. Dari dana memadai dan mencukupi, kegiatan terlaksana dengan baik hal ini ditunjukan dari kesesuaian jadwal dengan rencana dari sosialisasi hingga evaluasi berjalan dengan baik yang tertuang dalam dokumen Program Kerja Sekolah (PKS) SMK Negeri 1 Pabelan tahun 
diklat/2018/2019 yakni pencapaian target terlaksananya jadwal sudah 80\%. Namun, pada aspek sarana dan prasarana masih ada beberapa yang kurang yakni alat praktikum atau praktek kurang dari segi jumlah terutama peralatan yang spesial.

\section{Evaluasi Produk Program FDS di SMK Negeri 1 Pabelan}

Untuk mengukur keberhasilan dan perubahan yang terjadi dalam pelaksanaan program FDS di SMK Negeri 1 Pabelan. Keberhasilan program dapat dilihat dari evaluasi hasil belajar (akademik, nonakademik, pendidikan karakter). Hasil evaluasi aspek akademik pada SMK Negeri 1 Pabelan yaitu program FDS tidak berdampak bagi peningkatan akademik siswa ditunjukan dari hasil nilai kenaikan siswa kelas X hingga kelas XII menunjukan bahwa tidak adanya kenaikan yang signifikan, hasil tersebut menunjukan bahwa penerapan FDS di SMK negeri 1 Pabelan tidak mempengaruhi hasil akademik.

Meskipun pada nilai akademik program FDS tidak mempengaruhi hasil akademik,tapi pada aspek nonakademik mengalami peningkatan namun tidak terlalu signifikan. Hasil pencapaian menunjukan bahwa prestasi tahun 2017 sampai dengan tahun 2019, dapat dirata-ratakan bahwa prestasi yang diperoleh siswa pada tahun 2017 dengan rata-rata peringkat 2. Pada tahun 2018 prestasi yang diperoleh oleh siswa stabil dengan rata-rata peringkat 2. Sedangkan pada tahun 2019 prestasi siswa mengalami peningkatan yakni mendapat rata-rata peringkat 1. Hal tersebut sejalan dengan Hincapié (2014) dalam penelitiannya mengatakan bahwa para pendukung program FDS mengatakan bahwa FDS memberikan manfaat positif bagi prestasi dan perilaku siswa. Untuk aspek afektif atau pendidikan karakter juga terwujud dengan baik dan mengalami peningkatan setiap tahunnya, dengan hasil pencapaian yaitu terjadi penurunan pelanggaran tata tertib yang dilakukan siswa sejak tahun 2016/2017 hingga 2019/2020 sebanyak 28 pelanggaran. Program FDS membantu pembentukan kepribadian dan karakter, melalui pembiasaanpembiasaan yang guru berikan (David, dkk., 2017; Yuwono, 2017).

Berdasarkan hasil penelitian dan pemenuhan keriteria evaluasi dapat disimpulkan bahwa program FDS di SMK Negeri 1 Pabelan pada komponen produk mendapatkan kategori cukup, dikarenakan pada prestasi hasil belajar (akademik) tidak ada peningkatan yang signifikan yang berarti program FDS pada hasil belajar akademik di SMK Negeri 1 Pabelan tidak memiliki pengaruh yang berarti. Sedangkan dari segi prestasi non akademik ada peningkatan namun tidak terlalu signifikan yang ditunjukan dari meningkatnya prestasi siswa dalam mengikuti perlombaan-perlombaan. Meskipun demikian, tujuan pelaksanaan program FDS tercapai yaitu karakter membaik dan menjawab kebutuhan sekolah yaitu membantu orangtua dalam pengawasan anak yang ditunjukan oleh adanya penurunan jumlah pelanggaran tata tertib melalui pembiasaan-pembiasaan pendidikan karakter dan kegiatan keagamaan disekolah.

Berdasarkan aturan penyusunan kriteria yakni dengan menghitung banyaknya indikator didalam komponen, yang memenuhi persyaratan, maka hasil dari kriteria keberhasilan program FDS secara keseluruhan yang ditunjukkan oleh komponen CIPP yakni konteks mendapatkan kategori baik sedangkan dari input, proses dan produk dinilai cukup sehingga dapat disimpulkan bahwa pelaksanaan program FDS di SMK Negeri 1 Pabelan cukup baik dan efektif terlihat dari pemenuhan kriteria-kriteria evaluasi konteks input, proses, dan produk.

\section{SIMPULAN}

Berdasarkan pada hasil evaluasi menunjukkan bahwa dari komponen konteks, program FDS di SMK 1 Pabelan termasuk dalam kategori baik karena penerapan FDS tidak hanya semata-mata melaksanakan kebijakan dari pemerintah namun FDS dibutuhkan oleh seluruh stakeholder atau sekolah yakni untuk meningkatkan kualitas pendidikan dan pembentukan karakter siswa serta menjawab kebutuhan orangtua yang sebagian besar sibuk bekerja yakni membantu pengawasan anak. Dari komponen input, program FDS di SMK 1 Pabelan termasuk dalam kategori cukup karena menjawab kebutuhan sekolah atau stakeholder, sumber daya manusia yakni guru yang menjadi penanggung jawab kegiatan dipilih sesuai dengan keahlian dalam bidangnya tetapi dari segi jumlah dan kompetensi guru masih kurang yakni total jumlah guru 39 orang dan 28 orang guru tidak tetap. Namun, dari segi sarana prasarana dan dana memadai serta adanya mekaniseme pelaksanaan yang jelas dan sistematis. 
Dari komponen proses, program FDS di SMK 1 Pabelan termasuk dalam kategori cukup karena kegiatan-kegiatan berjalan dengan lancar dan sesuai dengan perencanaan, sumber daya cukup fungsional dikarenakan guru-guru mengayomi dan memfasilitasi kebutuhan siswa, memiliki keahlian dalam bidangnya, serta pembelajaran sudah menggunakan media meskipun dari segi jumlah guru masih kurang dan masih banyak guru yang tidak tetap, dana memadai dan mencukupi, jadwal dan mekanisme dari sosialisasi hingga evaluasi berjalan dengan lancar dan target pencapaian terlaksana jadwal dan mekanisme sudah $80 \%$. Namun sarana dan prasarana masih ada kurang yakni ada beberapa peralatan praktikum/bengkel yang dari segi jumlah ada yang kurang terutama peralatan tertentu.

Dari komponen produk, program FDS di SMK 1 Pabelan termasuk dalam kategori cukup karena pada hasil akademik tidak menunjukan adanya peningkatan yang signifikan. Pada hasil prestasi non akademik mengalami peningkatan meskipun tidak signifikan yaitu meningkatnya prestasi atau peringkat yg diperoleh siswa dalam mengikuti perlombaan. Meskipun demikian, tujuan dari pelaksanaan program FDS tercapai yaitu karakter siswa membaik yang ditunjukkan oleh adanya penurunan pelanggaran tata tertib serta nilai spiritual maupun sosial sebagian besar siswa baik dengan adanya pembiasaanpembiasaan disekolah dan pelbagai kegiatan yang positif lainnya.

\section{DAFTAR RUJUKAN}

Ananda, R., \& Rafida, M. (2017). Pengantar Evaluasi Program Pendidikan. Medan: Perdana Publishing, 53(9). https://doi.org/10.1017/CBO9781107415324.004.

Apriyani, A., Fatimah, N., \& Wicaksono, H. (2019). Dari Full Day School ke Kebijakan Enam Hari Sekolah: Rasionalisasi Praktik dan Evaluasi Pembelajaran Pasca Full Day School di SMA Negeri 1 Kedungreja Kabupaten Cilacap. Sosietas, 8(2), 532-542. https://doi.org/10.17509/sosietas.v8i2.14740.

Arikunto, S., \& Jabar, C. S. A. (2010). Evaluasi Program Pendidikan: Pedoman Teoritis Praktis bagi Mahasiswa dan Praktis Pendidikan. Jakarta: Bumi Aksara.

Baharuddin. (2010). Pendidikan dan Psikologi Perkembangan. Jogjakarta: Ar-Ruzz Media.

Danil, M. (2018). Implementation of Full Day School in Sabbihisma Padang. Jurnal Komunikasi Pendidikan, 2(1), 86-92.

David, M., Resky, A., Rahmi, S. N. R. A., Iffa, F., \& Ramadhani, N. I. (2017). Peran Full Day School terhadap Penanaman Karakter pada Peserta Didik Sekolah Dasar di Kota Makassar. Jurnal Penelitian dan Penalaran, 4(1), 772-780.

Hincapié, D. (2014). Do Longer School Days Improve Student Achievement? Evidence from Colombia. Association for Education Finance and Policy Annual Conference, March 13-15, hlm. 1-49. https://doi. org $/ 10.18235 / 0000268$.

Kurniawan, A. R., Chan, F., Pratama, A. Y., Yanti, M. T., Fitriani, E., \& Mardani, S. (2019). Analisis Degradasi Moral Sopan Santun Siswa di Sekolah Dasar. Jurnal Pendidikan IPS, 9(2), 104-112. https://doi.org/10.37630/ jpi.v9i2.189.

Leasa, M., \& Batlolona, J. R. (2017). Full Day School dalam Pembentukan Karakter Siswa SMKN 13 Kota Malang. Jurnal Ilmu Sosial dan Humaniora, 6(1), 73. https://doi.org/10.23887/jish-undiksha.v6i1.9903.

Ningrum, D. (2015). Kemerosotan Moral di Kalangan Remaja: Sebuah Penelitian Mengenai Parenting Styles dan Pengajaran Adab Diah Ningrum Sekolah Menengah Islam Terpadu (SMIT) Al Marjan. Unisia, XXXVII(82), $18-30$.

Peraturan Menteri Pendidikan dan Kebudayaan Nomor 23 Tahun 2017 tentang Lima Hari Sekolah. Jakarta: Kemdikbud.

Siregar, L. Y. S. (2017). Full Day School sebagai Penguatan Pendidikan Karakter (Perspektif Psikologi Pendidikan Islam). Fikrotuna, 5(1). https://doi.org/10.32806/jf.v5i1.2945.

Soapatty, L. (2014). Pengaruh Sistem Sekolah Sehari Penuh (Full Day School) terhadap Prestasi Akademik Siswa SMP Jati Agung Sidoarjo. E-Journal UNESA, 2(2), 719-733.

Tia, R. A., Zam, Z. Z., \& Pasongli, H. (2019). Evaluasi Program Pendidikan Full Day School dalam Pembentukan Karakter Siswa pada Mata Pelajaran Geografi di SMAN 4 Kota Ternate. Pangea Jurnal Geografi, 1(2), 51-64. 
Wirawan. (2012). Teori, Model, Standar, Aplikasi, dan Profesi: Contoh Aplikaso Evaluasi Program Pengembangan Sumber Daya Manusia, Program Nasional Pemberdayaan Masyarakat (PNPM) Mandiri Perdesaan, Kurikulum, Perpustakaan, dan Buku Teks. Jakarta: Rajawali Pers.

Yuwono, T. H. (2017). Full Day School: Realisasi Pembentukan Karakter Anak. Jurnal Pigur, 1(1), 73-80.

Zermeño, G. M. G., Fahara, M. F., \& Garza, L. A. (2014). The Full-Time School Program in Mexico. Journal of Case Studies in Education, 22(2), 1-15. 